\title{
A Functional Proteomics Screen of Proteases In Colorectal Carcinoma
}

\author{
James H. McKerrow ${ }^{1}$, Vivek Bhargava ${ }^{1}$, Elizabeth Hansell ${ }^{1}$, Sandra Huling ${ }^{3}$, \\ Thomas Kuwahara', Mary Matley ${ }^{1}$, Lisa Coussens ${ }^{1,4}$, and Robert Warren ${ }^{2}$ \\ Departments of ${ }^{1}$ Pathology and ${ }^{2}$ Surgery, ${ }^{3}$ The Liver Center, and ${ }^{4}$ The Hormone \\ Research Laboratory, University of California, San Francisco, CA, U.S.A. \\ Communicated by F. E. Cohen. Accepted March 8, 2000.
}

\begin{abstract}
Background: Proteases facilitate several steps in cancer progression. To identify proteases most suitable for drug targeting, actual enzyme activity and not messenger RNA levels or immunoassay of protein is the ideal assay readout.

Materials and Methods: An automated microtiter plate assay format was modified to allow detection of all four major classes of proteases in tissue samples. Fifteen sets of colorectal carcinoma biopsies representing primary tumor, adjacent normal colon, and liver metastases were screened for protease activity. Results: The major proteases detected were matrix metalloproteases (MMP9, MMP2, and MMP1), cathepsin B, cathepsin D, and the mast cell serine proteases, tryptase and chymase. Matrix metalloproteases were expressed at higher levels in the primary tumor than in adjacent normal tissue. The mast cell proteases, in contrast, were at very high levels in adjacent normal tissue, and not detectable in the metastases. Cathepsin B activity was significantly higher in the primary tumor, and highest in the
\end{abstract}

metastases. The major proteases detected by activity assays were then localized in biopsy sections by immunohistochemistry. Mast cell proteases were abundant in adjacent normal tissue, because of infiltration of the lamina propria by mast cells. Matrix metalloproteases were localized to the tumor cells themselves; whereas, cathepsin B was predominantly expressed by macrophages at the leading edge of invading tumors. Although only low levels of urinary plasminogen activator were detected by direct enzyme assay, immunohistochemistry showed abundant protein within the tumor.

Conclusions: This analysis, surveying all major classes of proteases by assays of activity rather than immunolocalization or in situ hybridization alone, serves to identify proteases whose activity is not completely balanced by endogenous inhibitors and which may be essential for tumor progression. These proteases are logical targets for initial efforts to produce low molecular weight protease inhibitors as potential chemotherapy.

\section{Introduction}

Studies that detect key biochemical differences between tumor cells and their normal counterparts are rapidly progressing from traditional cell culture studies to direct analysis of tumor and normal tissue from animal models or human specimens. High throughput screens designed to identify key molecular differences include "genomics" microchip analysis of gene expression, "proteomics" analysis of protein

Address correspondence and reprint requests to: James $\mathrm{H}$. McKerrow, Ph.D., M.D., Department of Pathology, UCSF/VA Medical Center, 4150 Clement Street - 113B, San Francisco, CA 94121, U.S.A. Phone: 415-476-2940; Fax: 415-750-6947; Email: jmck@cgl.ucsf.edu expression by two-dimensional gel analysis, and "functional" proteomics screens for specific classes of enzymes. Proteases are particularly suitable for functional proteomics screens, because of the availability of fluorescent substrates for high throughput assays. Proteases have been implicated in tumor cell invasion and metastasis, and more recently, in angiogenesis and tumor growth. The development of new low molecular weight protease inhibitors for each of the major classes of proteolytic enzymes has renewed interest in the role of proteases in tumor progression and the potential for protease inhibitors in cancer chemotherapy. Although a substantial body of literature exists on protease expression in various human tu- 
mors, most reports focus on a single class of proteases (1-8). A variety of techniques to detect proteases were used, making comparisons among the studies difficult and data reported from different studies often inconsistent. Furthermore, from the perspective of medicinal chemistry, the most useful data would be direct analysis of protease activity. Previous studies used immunohistochemistry (9-12) or in situ hybridization (13-17) to identify proteases without parallel analysis of enzyme activity. The presence of messenger RNA or even immunologically detectable protease may not correlate with protease activity if the enzyme is present as a proform or is complexed with an endogenous inhibitor.

To identify major proteases that might be suitable targets for inhibitor development, we undertook a study of 15 matched sets of colon carcinoma biopsies that included primary tumor, adjacent normal tissue from the same colon, and liver metastasis. All samples were taken at the time of primary surgery and all represented moderately differentiated, Duke C tumors. An additional seven sets of primary tumor were obtained to confirm results from matrix metalloproteases (MMP) assays by zyrogram. We first assayed for major protease activity representative of all four major classes of proteases. Matrix metalloproteases, the cysteine protease cathepsin $\mathrm{B}$, serine proteases from mast cells, and cathepsin D were identified as the major active (and therefore uninhibited) proteases in colorectal carcinomas. These individual protease species were then localized to tumor cells or stromal components of the tumor by immunohistochemistry or in situ hybridization.

\section{Materials and Methods}

Protease Assays

Tissue eXtracts. Frozen tissue samples from time-matched colon cancers sets (tumor, adjacent $(5 \mathrm{~cm})$ normal tissue, and liver metastases stored at $-70^{\circ} \mathrm{C}$ ), were homogenized in $250 \mu \mathrm{l} / \mathrm{mg}$ ice cold phosphate-buffered saline (PBS) with $0.1 \%$ Triton X-100 using a Tenbrock homogenizer on ice. The homogenate was centrifuged in a microfuge at $16 \mathrm{Kg}$ for 10 min at $4^{\circ} \mathrm{C}$. The supernatant was used as "low salt extract." "High salt extracts" were prepared by resuspending the pellets at $10 \mu \mathrm{l} / \mathrm{mg}$ in
$50 \mathrm{mM}$ Na Acetate, pH 6.1, $2 \mathrm{M} \mathrm{NaCl}$, vortexing for $3 \mathrm{~min}$ and collecting the supernatants as above. Protein concentration was determined by Bradford analysis using a bovine serum albumin standard (Bio Rad, Hercules, California). Pellets and aliquoted supernantants were stored at $-70^{\circ} \mathrm{C}$.

PROTEASE ACTIVITY ASSAYS. Fluorogenic peptide substrates were used to assay the activity in the colon tissue extracts and control conditioned media. Release of fluorescent product was followed at room temperature with a 96well fluorometric plate reader (Fluoroskan II, LabSystems, Franklin, MA).

GENERAL CYSTEINE PROTEINASE ACTIVITy. General cysteine proteinase activity was assayed (ex 366, em 405) in $100 \mathrm{mM} \mathrm{Na}$ Acetate, pH 6.5, containing $10 \mathrm{mM}$ DTT Buffer A using either Cbz-Phe-Arg-AMC, or Cbz-Arg-Arg-AMC at $20 \mu \mathrm{M}$ [Bachem, King of Prussia, PA, from $20 \mathrm{mM}$ stocks in dimethylsulfoxide (DMSO)]. Controls of extract buffer alone, bovine cathepsin B (Sigma, St. Louis, MO) and recombinant cruzain (a cathepsin L-like protease) were included. Specificity of activity was tested by preincubating samples for $30 \mathrm{~min}$ at room temperature with the general cysteine proteinase inhibitor, E64 (Sigma; 20 mM stock in DMSO) at $10 \mu \mathrm{M}$, or the specific cathepsin $\mathrm{B}$ inhibitor, CA-074 (a gift of Taisho Pharmaceutical Co., Ltd. [Santa ma, Japan]; $200 \mu \mathrm{M}$ stock in DMSO) at $1 \mu \mathrm{M}$, or DMSO at equivalent $\%$ (volume per volume, v/v) alone. Cathepsin Klike activity was followed with Cbz-Gly-ProArg-AMC (Bachem) in buffer A at $20 \mu \mathrm{M}$.

Cathepsin D-like activity (aspartyl proteinase) was assayed in 0.1 word $\mathrm{M}$ glycine, $\mathrm{pH}$ 3.7, using $5 \mu \mathrm{M}$ Dabcyl-Glu-Arg-norLeu-PheLeu-Ser-Phe-Pro-EDANS (ex 355, em 485 (Bachem). Human cathepsin D (Sigma) was used as a control. Specificity of activity was tested by pre-incubating the samples for 30 min in $1 \mu \mathrm{M}$ Pepstatin A (100 $\mu \mathrm{M}$ in DMSO; Sigma) or DMSO alone.

General serine proteinase activity was assayed in $50 \mathrm{mM} \mathrm{TCl}, \mathrm{pH} 8.2,150 \mathrm{mM} \mathrm{NaCl}$, $5 \mathrm{mM} \mathrm{CaCl}_{2}$ (Buffer B) using $100 \mu \mathrm{M} \mathrm{Cbz-Arg-}$ Arg-AMC. Specificity of activity was determined by pre-incubating the samples for $30 \mathrm{~min}$ in $1 \mathrm{mM}$ phenylmethylsulfonyl fluoride (PMSF) (100 mM stock in DMSO, Sigma), $10 \mu$ M E64 or DMSO alone. Urinary plasminogen activator 
activity was assayed with $20 \mu \mathrm{M}$ Glutaryl-GlyArg-AMC (Bachem) in $50 \mathrm{mM}$ Tris, $\mathrm{pH} \mathrm{8.8,50}$ $\mathrm{mM} \mathrm{NaCl}$ with $0.01 \%$ Tween 80 . Controls of human high molecular weight urokinase plasminogen activator (UPA) (American Diagnostics, Greenwich, CT), and conditioned media from a human prostate cell line (PC3) were included. Prostate-specific antigen-like (PSA) activity was assayed with $200 \mu \mathrm{M}$ morpholine carboxyl-His-Ser-Ser-Lys-Leu-Gln-AMC $\quad(20$ mM stock in DMSO, Enzyme Systems Products, Livermore, CA) in buffer B. Specificity of activity was determined by pre-incubating samples with PMSF and E64 inhibitors (as above). Plasmin activity was assayed with 20 $\mu \mathrm{M}$ Z-Ala-Phe-Lys-AMC (Enzyme Systems Products) in buffer B. Chymase activity was assayed with $1 \mathrm{mM}$ Suc-Ala-Ala-Pro-Phe-pNA (Enzyme Systems Products) using a spectrophotometric 96-well microplate reader (absorbance: 405 nM; Vmax, Molecular Devices, Sunnyvale, CA) on normal and high-salt extracted colon tissue samples in $0.45 \mathrm{M}$ Tris, pH8, $1.8 \mathrm{M} \mathrm{NaCl}$ or buffer B. Tryptase activity was assayed in normal and high-salt colon tissue extracts with $50 \mu \mathrm{M}$ BOC-Ala-Gly-ProArg-AMC (Enzyme Systems Products) in $50 \mathrm{mM}$ Tris $\mathrm{HCl}, \mathrm{pH} 8.2$, with or without $10 \mu \mathrm{M}$ heparin. Specificity of activity was determined by pre-incubating the samples with $10 \mu \mathrm{M}$ alpha1-anti-trypsin (Sigma) for 30 min (tryptase is not inhibited by alpha-1-anti-trypsin).

ZYMOGRAPHY. Acidic or neutral proteinase activity was detected in 10-15 $\mu$ l samples from tissue extracts, following separation on SDSpolyacryalmide minigels copolymerized with $1 \mathrm{mg} / \mathrm{ml}$ type I gelatin (Sigma) or $1 \mathrm{mg} / \mathrm{ml} \mathrm{ca-}$ sein (Sigma). After electrophoresis, gels were washed 2 times for $15 \mathrm{~min}$ in $2.5 \%$ Triton $\mathrm{X}$ 100 , in acidic or neutral developing buffer, to reactivate enzymes by removal of SDS. Gels were rinsed for $30 \mathrm{~min}$, followed by 15 to $24 \mathrm{hr}$ incubation at $37^{\circ} \mathrm{C}$ on a rocking platform in developing buffer. Acid developing buffer was $0.1 \mathrm{M}$ Na Acetate, pH 5.5, with 10 mM DTT, and the neutral developing buffer was $50 \mathrm{mM}$ Tris $\mathrm{HCl}, \mathrm{pH} 8.2,150 \mathrm{mM} \mathrm{NaCl}$, with $5 \mathrm{mM}$ $\mathrm{CaCl}_{2}$. To demonstrate specific proteinase activities, samples were pre-incubated for $30 \mathrm{~min}$ with class-specific inhibitors and gels were also incubated in developing buffer with the corresponding class-specific inhibitors. These included ImM PMSF (Sigma, $100 \mathrm{mM}$ in DMSO), 1 mM 1, 10-orthophenanthroline
(Sigma, $100 \mathrm{mM}$ in DMSO), $1 \mathrm{mM}$ E64, (Sigma, $100 \mathrm{mM}$ in DMSO), DMSO (Sigma) at equivalent $\%(\mathrm{v} / \mathrm{v})$, or $10 \mu \mathrm{M}$ recombinant Ecotin (gift of C. Craik, University of California, San Francisco, CA). Activities were compared with conditioned media from cell lines with known proteinase activities: firsttrimester cytotrophoblast (CTB) cells media with MMP-2 and MMP-9 activity (CTB, a generous gift of Susan Fisher, University of California, San Francisco, CA) and human prostate cancer line (PC3) with UPA and MMP-2, and MMP-9 activity. To detect areas of protease digestion (clear bands against a dark background), gels were stained in $0.5 \%$ (weight per volume, w/v) Coomassie Blue R250 (Sigma) in $10 \%(\mathrm{v} / \mathrm{v})$ acetic acid, $50 \%(\mathrm{v} / \mathrm{v})$ methanol for $30 \mathrm{~min}$ at room temperature on a rocking platform, followed by destaining in $10 \%(\mathrm{v} / \mathrm{v})$ acetic acid and $40 \%(\mathrm{v} / \mathrm{v})$ methanol.

MMP-3 (stromelysin-1) activity was also assayed with $1 \mu \mathrm{M}$ MCA-Arg-Pro-Lys-ProVal-Glu-Nva-Trp-Arg-Lys (DNP)-NH2 in buffer B, (ex 325 em 393; $10 \mathrm{mM}$ stock in DMSO; Bachem) using the PE LS30 fluorimeter (Perkin-Elmer, Norwalk, CT). This substrate has low sensitivity for MMP-9. Activity was compared with CTB conditioned media (CM). Specificity of activity was determined by pre-incubating the samples with $1 \mathrm{mM} 1,10$ orthophenanthroline for $30 \mathrm{~min}$, or DMSO alone.

MMP-9 (gelatinase B) and MMP-1 (collagenase 1) activities were also assayed with $5 \mu \mathrm{M}$ DNP-pro-beta-cyclohexyl-Ala-GlyCys(Me)-His-Ala-Lys (N-Me Abz)-NH2 (ex 365 em 450;10 mM stock in DMSO; Bachem) in buffer B. Activity was compared with recombinant fiddler crab collagenase (a serine proteinase), and CTB CM. Specificity of activity was determined by pre-incubating with 1,10 orthophenanthroline as above.

IMMUNOPEROXIDASE LOCALIZATION OF CATHEPSIN B, L, D AND MMPS. The following antibodies were used, all at 1:100 dilution: cathepsin B (Enzyme Systems Products); cathepsin D (DAKO Corporation, Carpentaria, CA); cathepsin L (Enzyme Systems Products); anti-human matrix metalloproteases 1, 2, 3, 9 (ICN Biomedicals, Inc., Aurora, $\mathrm{OH})$; anti-human matrix metalloproteases 1,3, and 9 from Calbiochem (Oncogene Research Products, CalbiochemNovabiochem Corp., San Diego, CA). AntiMMP 2 and MMP 9 came from Dr. William 
Stetler-Stevenson, National Cancer Institute, Bethesda, MD.

Antibody staining was done on $10 \%$ phosphate-buffer formalin-fixed, paraffinembedded human tissue, 4 microns thick, on charged slides utilizing the Ventana ES automated stainer (Ventana Medical Systems, Tucson, AZ), according to the following protocol: Xylene, 2 times for $6 \mathrm{~min}$ each; absolute alcohol, 2 times for 10 dips each; 95\% alcohol, 2 times for 10 dips each; $80 \%$ alcohol, 10 dips; distilled water, 10 dips; tap water for 5 min; TRIS-HCL Buffer (Ventana), pH 7.2, for 5 min, two changes; digestion with pronase e, 1 $\mathrm{mg} / \mathrm{ml}$ solution (Sigma) in TRIS-HCL buffer, for $4.5 \mathrm{~min}$ at $37^{\circ}$. (Cathepsin D slides had digestion per manufacturer's recommendation.) This was followed by a rinse in TRIS buffer for 5 min, with 2 changes, and $2 \%$ casein in TRIS buffer for $30 \mathrm{~min}$. Color reaction was developed by Ventana ES stainer with StreptAvidin detection kit, DAB substrate and hematoxylin counterstain (Ventana). All slides were dehydrated through ascending alcohols and xylene 3 times and mounted in Cytoscal 60 (Stevens Scientific, Riverdale, NJ).

IMMUNOLOCALIZATION OF MAST CELL CHYMASE. Fresh tissues obtained at resection (primary tumor, adjacent normal mucosa and liver metastasis) were immersion-fixed overnight at $4^{\circ} \mathrm{C}$ in $3.75 \%$ paraformaldehyde prepared in phosphate-buffered saline (PBS), followed by embedding and freezing at $-80^{\circ} \mathrm{C}$ in Tissue-Tek O.C.T. (Sakura FineTechnical Co., Ltd., Tokyo, Japan). $10 \mu \mathrm{m}$-thick sections were cut on a Leica CM1900 cryostat (Leica, Deerfield, PA) and placed on slides. Tissues were then dried $2 \mathrm{hr}$ at room temperature, subsequently fixed with ice-cold acetone ( $5 \mathrm{~min}$ ), followed by airdrying. Tissues were rehydrated in PBS, followed by immunolocalization of mast cell chymase, MAB 1254B, (Chemicon International, Inc.) using standard protocols.

IN SITU HYBRIDIZATION OF CATHEPSIN B. The cathepsin B sense and antisense probes (a gift of Dr. Bonnie Sloane, Wayne State University, Detroit, MI) were labeled with digoxigenin using the Boeringer Mannheim Genius 4 System (subsidiary of Roche Molecular Biochemicals, Indianapolis, IN). The rehydrated slides were placed in $0.2 \mathrm{~N} \mathrm{HCl}$ in depc PBS for 20 min and then treated with $0.3 \%$ Triton X-100 in depc PBS for $15 \mathrm{~min}$. The tissue was per- meablized with proteinase $\mathrm{K}(15 \mu \mathrm{g} / \mathrm{ml})$ for $30 \mathrm{~min}$ at $37^{\circ} \mathrm{C}$ in $10 \mathrm{mM}$ Tris- $\mathrm{HCl}, \mathrm{pH} 8.0$, buffer with $500 \mathrm{mM} \mathrm{NaCl}$. After a rinse in PBS, sections were postfixed in $4 \%$ paraformaldehyde in $0.1 \mathrm{M}$ phosphate buffer, $\mathrm{pH} \mathrm{7.4,} \mathrm{for} 5 \mathrm{~min}$ at room temperature. The slides were then acetylated in $0.1 \mathrm{M}$ triethanolamine, $\mathrm{pH} 8.0$, containing $0.25 \%$ acetic anyhdride 2 times for $5 \mathrm{~min}$. After a $4 \mathrm{X}$ SSC rinse, the slides were prehybridized in $4 \mathrm{X} \mathrm{SSC}$ in $50 \%$ formamide $(50-100 \mu \mathrm{l})$ for 3 $\mathrm{hr}$ at $42^{\circ} \mathrm{C}$. The solution was then changed to hybridization solution containing 25-75 ng/ slide of labeled cathepsin $\mathrm{B}$ and incubated at $50^{\circ} \mathrm{C}$ overnight. The hybrization solution contained $40 \%$ deionized formamide, $10 \%$ dextran sulfate, IX Denhardt's solution, $4 \mathrm{X}$ SSC, $10 \mathrm{mM}$ DTT, $1 \mathrm{mg} / \mathrm{ml}$ yeast tRNA and $1 \mathrm{mg} / \mathrm{ml}$ denatured/sheared salmon sperm DNA. The post hybridization washes were as follows: $2 \mathrm{X}$ SSC for $30 \mathrm{~min}$ at room temperature, $2 \mathrm{X} \mathrm{SSC}$ for $30 \mathrm{~min}$ at $37^{\circ} \mathrm{C}, 2 \mathrm{X} \mathrm{SSC}$ with $50 \%$ formamide for $15 \mathrm{~min}$ at $50^{\circ} \mathrm{C}$, and then IX SSC for $30 \mathrm{~min}$ at $37^{\circ} \mathrm{C}$. The unbound RNA probe was digested with a solution containing RNAse A (20 ug/ml) for $30 \mathrm{~min}$ at $37^{\circ} \mathrm{C}$. The digestion was followed by washes of $0.1 \mathrm{X}$ SSC for $30 \mathrm{~min}$ at $37^{\circ} \mathrm{C}, 0.1 \mathrm{X} \mathrm{SSC}$ and $0.1 \%$ SDS for $15 \mathrm{~min}$ at $50^{\circ} \mathrm{C}$ and, finally, $100 \mathrm{mM}$ Tris-HCl, $\mathrm{pH}$ 7.5, containing $150 \mathrm{mM} \mathrm{NaCl}$ (Buffer 1) for $10 \mathrm{~min}$ at room temperature. The sections were blocked in $2 \%$ sheep serum in Buffer 1 and $0.1 \%$ Triton X-100 for $30 \mathrm{~min}$. The Boehringer Mannheim anti-digoxigenin (DIG) (DIG Detection Kit) $1^{\circ}$ antibody was diluted $1: 250$ in Buffer 1 plus $0.1 \%$ Triton $X$ 100 plus $1 \%$ sheep serum for $120 \mathrm{~min}$. The slides were then rinsed in $100 \mathrm{mM}$ Tris- $\mathrm{HCl}$, $\mathrm{pH}$ 9.5, with $100 \mathrm{mM} \mathrm{NaCl}$ and $50 \mathrm{mM}$ $\mathrm{MgCl}_{2 \mathrm{f}}$ at $4^{\circ} \mathrm{C}$. The color reaction was run according to kit instructions, containing levamisole, overnight at $4^{\circ} \mathrm{C}$. The slides were counterstained in $0.5 \%$ methyl green and mounted with aqueous mounting media.

The sense and antisense cathepsin $B$ probes were also labeled with Amersham dUTP- ${ }^{35} \mathrm{~S}$ (SJ1303) using the Ambion Maxiscript kit. All the in situ preliminary steps were the same as those for the DIG-labeled riboprobes. The prehybridization and hybridization solutions consisted of $50 \%$ deionized formamide, $10 \%$ dextran sulfate, IX Denhart's solution, $10 \mathrm{mM}$ DTT, $5 \mathrm{mM}$ EDTA, $0.3 \mathrm{M} \mathrm{NaCl}$ and $20 \mathrm{mM}$ Tris- $\mathrm{HCl}, \mathrm{pH}$ 8.0. The slides were hybridized with $600,000 \mathrm{cpm} /$ slide of either sense or anti- 
sense cathepsin B. The second-day washes were 2X SSC with $\beta$-mercaptoethanol (BME) and EDTA, 4 times for $10 \mathrm{~min}$ each, at room temperature. The sections were then digested with RNaseA $(30 \mu \mathrm{g} / \mathrm{ml})$ for $30 \mathrm{~min}$ at $37^{\circ} \mathrm{C}$; followed by rinses of $2 \mathrm{X}$ SSC with BME and EDTA, 2 times for $10 \mathrm{~min}, 2 \mathrm{X}$ SSC (BME and EDTA) plus $50 \%$ formamide for $10 \mathrm{~min}$ at room temperature; $2 \mathrm{X}$ SSC(BME and EDTA) plus $50 \%$ formamide for $10 \mathrm{~min}$ at $55^{\circ} \mathrm{C} ; 0.1 \mathrm{X}$ SSC(BME,EDTA), at least 4 liters for $120 \mathrm{~min}$ at $55^{\circ} \mathrm{C}$; then $0.5 \mathrm{X} \mathrm{SSC}$, twice at room temperature for $10 \mathrm{~min}$ each. The slides were then dehydrated in 50, 70, and $90 \%$ EtOH with $0.3 \mathrm{M}$ $\mathrm{NH}_{4} \mathrm{OAc}$ for 2 min each, dried in a vacuum, and coated with photographic emulsion Ilford K5D (Polyscience, Warrington, PA) for 3-7 days.

The final slides were developed with D-19 (Kodak, Rochester, NY), stained with hematoxylin, dehydrated and coverslipped. The slides were analyzed using a darkfield condenser and brightfield lens.

\section{Statistical Analysis}

$p$-values for pairwise comparison of primary tumor to normal tissue, metastasis to normal tissue, or metastasis to primary tumor were determined by paired $t$-tests using GraphPad Prism 2.0 software (GraphPad, San Diego, CA).

\section{Results}

\section{Major Proteases Detected in Colon Biopsies and Correlation with Tumor Progression}

Table 1 and Figure 1 summarize results of the quantitative solution assays and gelatin zymograms of colon or tumor tissue samples. The assays screened for a spectrum of proteolytic activity, representing all four major classes of proteases. Where possible, commercially available substrates not requiring custom synthesis were used. In most cases, AMC substrates were used to allow cross-comparison of activity. The major protease activities of the colon cancer specimens included the matrix metalloproteases (MMP9, MMP2 and MMP1), cathepsin B, cathepsin D and the mast cell serine proteases, tryptase and chymase. An unidentified trypsinlike activity cleaving Z-FR-AMC at neutral pH was also noted. We detected low levels of uPAlike activity or plasmin, but no significant activity attributable to PSA or cathepsin K (not shown). Class-specific protease activity was confirmed by use of class-specific inhibitors and, in some cases, specific protease species were identified by specific inhibitors or by correlation with migration of protease standards on gelatin zymograms (Fig. 1).

Relative amounts of protease activity were ascertained for those proteases that could be measured with the AMC assay. Mast cell serine protease activity (tryptase and chymase) was very high in normal tissue adjacent $(5 \mathrm{~cm})$ to the tumor mass. This correlated with a mast cell infiltrate noted by immunohistochemistry adjacent to the tumor (Fig. 2). No activity (or mast cells) was detected in liver metastases. Cathepsin B activity was significantly higher in the primary tumor versus adjacent normal tissue, and highest in the metastasis. One cannot compare absolute levels of activity between assays requiring different substrates (e.g., cathepsin D or MMPs versus cathepsin B or mast cell proteases). However, gelatin zymograms or direct assay suggested that MMPs 1 , 2 , and 9 were expressed at higher levels in the primary tumor versus adjacent normal tissue. In the case of MMP2, zymogram analysis (Fig. 1) suggested there was more activated MMP2 in primary tumor and metastatic samples than in normal tissue, although the proenzyme species was expressed at similar levels. 20 out of 22 primary tumors assayed, (15 from the initial set, plus 7 additional primary tumors) showed activated MMP2 and always at higher levels than adjacent normal tissue. Although the proform of MMP9 was expressed at higher levels in 19 out of 22 primary tumors, activated MMP9 was detected in only 13 out of 22 primary tumor biopsies assessed by gelatin zymogram (see example in Fig. 1). All the primary tumor specimens were from tumors with a histologic grade of "moderately well differentiated," Duke C.

\section{Localization of Protease Activity}

The major protease activities detected were then localized through the use of specific and, where possible, commercially available antibodies. In each case, we tested several commercial sources of antibody and selected those that were suitable for paraffin-embedded sections and demonstrated low background. A caveat for others pursuing similar analyses was that we found several antibodies bound nonspecifically to collagen in tumor matrix. To con- 


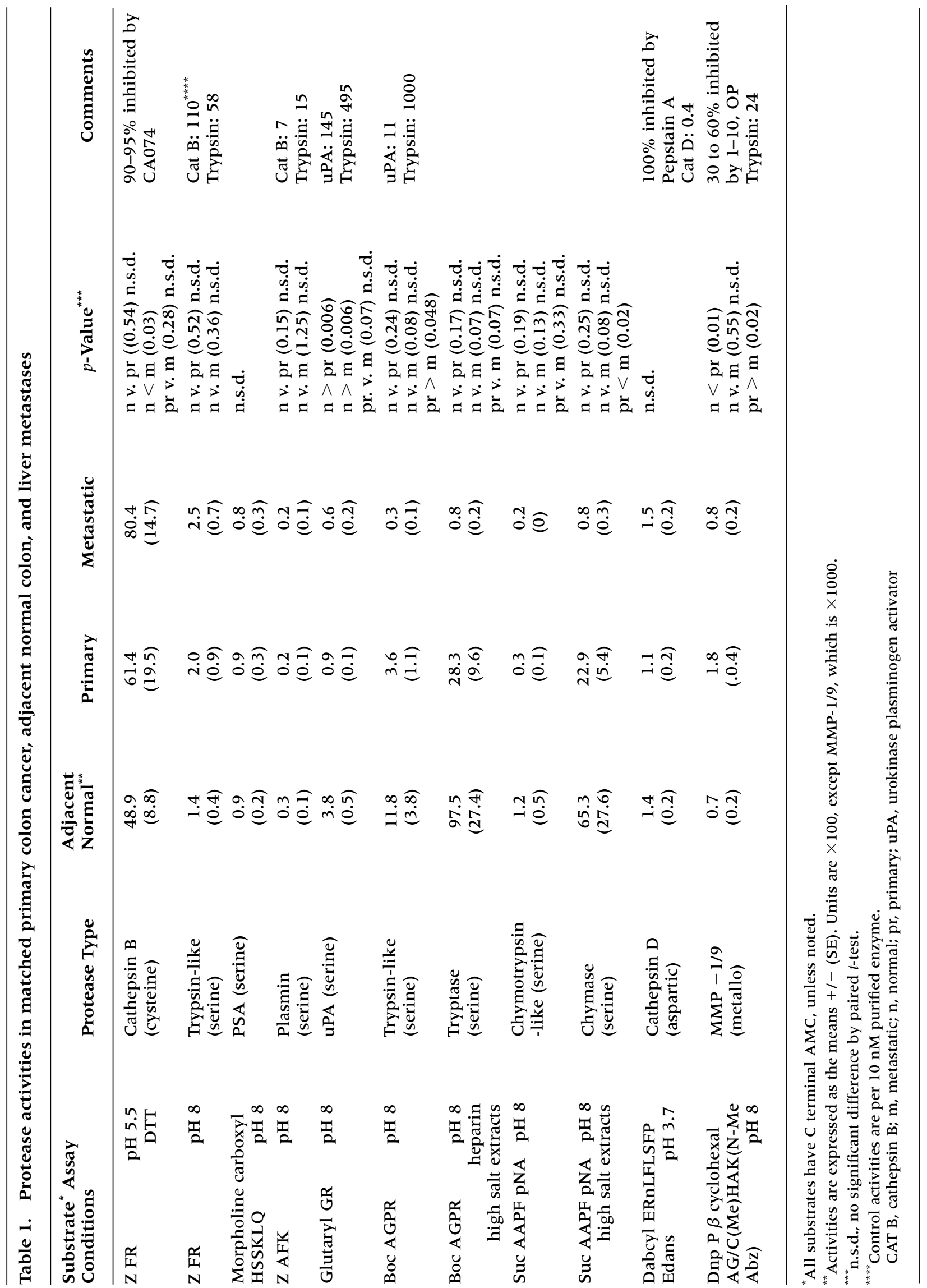




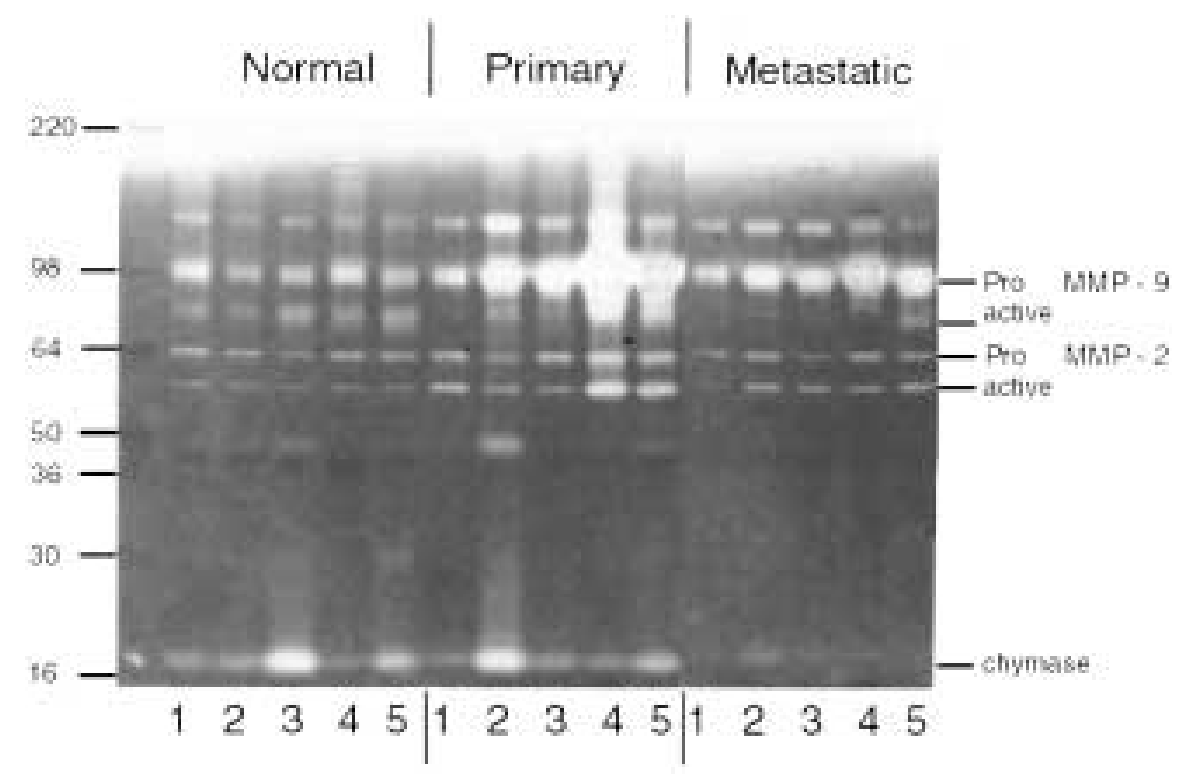

Fig. 1. Gelatin gel zymogram to identify protease species. Examples of 5 matched sets of normal colonic mucosa ( $5 \mathrm{~cm}$ from tumor), primary carcinoma, and liver metastasis, each from the same patient. Protease species identified by co-migration with purified standards and inhibition by class-

firm matrix localization, blocking with antigen or confirmatory in situ hybridization should be carried out. Table 2 summarizes localization in normal tumor and metastatic lesions for each of the major classes. Examples of histology are shown in Figure 2. Figures 2B and 2D show matrix metalloprotease activity localized to the specific inhibitors (see "Materials and Methods"). Note variation in some species from patient to patient, especially for chymase and for activated matrix metalloproteases (MMP9) in primary tumors (See "Results" for more detail).

tumor cells themselves in both primary and metastatic carcinomas. Cathepsin D activity was detected in both tumor cells and macrophages in adjacent stroma (Fig. 2A). uPA, while not detectable as an active protease in primary tumor tissue (Table 1), was nevertheless relatively abundant in tumor as detected

Table 2. Localization of major proteases by immunohistochemistry

\begin{tabular}{|c|c|c|c|}
\hline \multicolumn{4}{|c|}{ Tissue Sample } \\
\hline Protease & Adjacent Normal Colon & Primary & Metastasis \\
\hline MMP-1 & + in superficial mucosa & +++ in tumor cells & +++ in tumor cells \\
\hline MMP-3 & + in superficial mucosa & +++ in tumor cells & +++ in tumor cells \\
\hline MMP-9 & not detected & +++ in tumor cells & \\
\hline Cathepsin D & $\begin{array}{l}+ \text { in macrophages, ganglion } \\
\text { cells; - in mucosa }\end{array}$ & $\begin{array}{l}\text { Focally + in tumor, } \\
\text { macrophages of stroma }\end{array}$ & $\begin{array}{l}\text { Focally }+ \text { in tumor and } \\
\text { macrophages }\end{array}$ \\
\hline Cathepsin B & $\begin{array}{l}\text { Occasional }+ \text { in macrophage } \\
\text { in lamina propria }\end{array}$ & $\begin{array}{l}+ \text { in occasional tumor cells, } \\
+++ \text { in macrophages of } \\
\text { stroma }\end{array}$ & $\begin{array}{l}+ \text { in occasional tumor cells, } \\
+++ \text { in macrophages of } \\
\text { stroma }\end{array}$ \\
\hline Mast cell chymase & $\begin{array}{l}+++ \text { in mast cells adjacent } \\
\text { to tumor }\end{array}$ & & No activity \\
\hline uPA & + in mucosa and stroma & + in tumor cells and stroma & + in tumor cells and stroma \\
\hline
\end{tabular}

+ , present but weak staining; - , absent; +++ , strong staining (See Figure 1 for photos)

MMP, matrix metalloproteases; wPA, urokinase plasminogen activator 


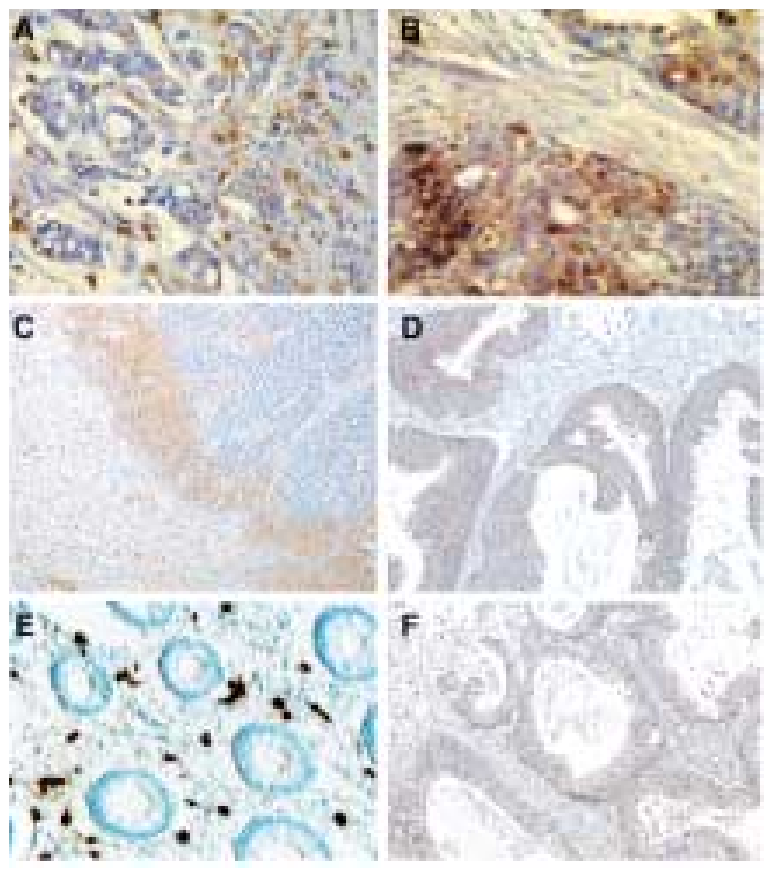

Fig. 2. Immunoperoxidase localization of major proteases detected. (A) Cathepsin D localization within both macrophages (in stroma on right) and tumor cells (400X). Macrophages were identified by CD68 labeling as described in "Materials and Methods" and Figure 3. (B) MMP-9 localization within tumor cells (400X). (C) Cathepsin B present at the interface of metastatic tumor (right) and hepatic parenchyma (left) (200X). (D) MMP-1 localization in tumor cells. Note staining at both apex and base of tumor cells $(200 X)$. (E) Mast cell chymase present in mast cells within adjacent benign colonic mucosa $(400 \mathrm{X})$. (F) Uniform uPA localization in tumor cells $(200 \mathrm{X})$. by immunohistochemistry (Fig. 2F). The high levels of mast cell chymase seen in adjacent normal colon (Table 1) correlated with an infiltrate of mast cells in the lamina propria adjacent to the tumor (Fig. 2E). Cathepsin B was especially prominent extracellularly, at the interface between the invading tumor and normal tissue (Fig. 2C).

\section{In situ Hybridization to Confirm Origin of Cathepsin B}

Because cathepsin B was found predominantly extracellularly, in situ hybridization with a 512 bp riboprobe (a gift of Dr. Bonnie Sloane, Wayne State University) was used to confirm the major cellular source. Figure $3 \mathrm{~A}$ shows cathepsin B mRNA was predominantly expressed just outside the edge of the invading tumor mass by cells identified as macrophages by CD68 antibody (Fig. 3B).

\section{Discussion}

An automated microtiter plate-based assay was used to survey protease activity in 15 colorectal carcinoma tissue sets that included biopsies of primary tumor, adjacent $(5 \mathrm{~cm})$ normal colon, and a liver metastasis. Our main goal was to identify "uninhibited" proteases that would be logical initial targets for the development of low molecular weight protease inhibitors as novel cancer chemotherapy. The major protease

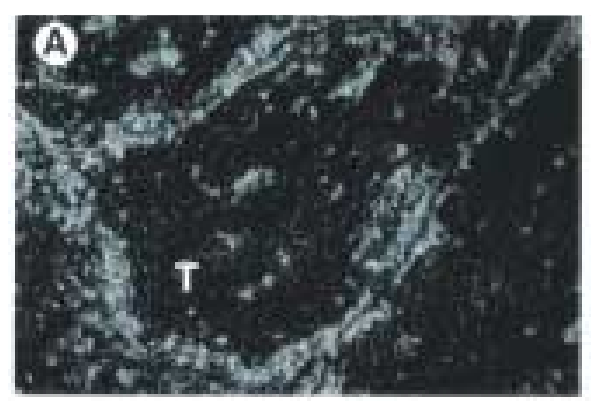

Fig. 3. Cathepsin B. (A) Darkfield micrograph of cathepsin B in situ hybridization demonstrating expression in macrophages at tumor $(\mathrm{T})$-stroma interface. Dark areas on the right are invasive nests of tumor cells, as seen in Figure 2C and Figure 3B. Note focal expression within tumor nests identified as macrophages trapped within tumor or within bands of stroma (see Fig. 3B). (B) CD68 antibody

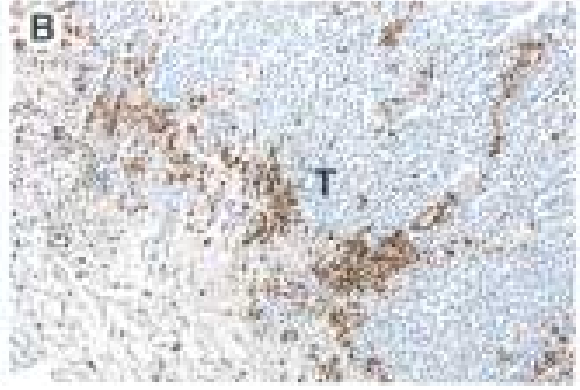

localization to identify macrophages at tumor (T)stroma interface (200X). Note most macrophages are at the interface between the tumor on the right and hepatic parenchyma on lower left. Some macrophages are also in strands of stroma within tumor masses on right. Compare with Figures $3 \mathrm{~A}$ and $2 \mathrm{C}$. 
activity identified was consistent with matrix metalloproteases, cathepsin B, and mast cell serine proteases. Significant cathepsin D activity was also detected, but cannot be directly compared with the other classes of proteases because of differences in substrate extinction coefficients. The assays employed will detect only activity that is above any "balance" between proteases and their endogenous inhibitors. For example, uPA was easily detected by immunohistochemistry in primary tumor tissue, but no significant activity was evident by direct assay with an AMC peptide substrate or by zymogram. Significant uPA activity was detected in normal tissue adjacent to the tumor. Positive controls for UPA (the PC3 prostate carcinoma cell line) confirmed that the assays used were sensitive and appropriate. Presumably, the uPA present in tumor cells is either not activated or is complexed with its endogenous inhibitor.

The matrix metalloproteases identified (predominantly MMP2 and 9 by gelatin zymograms) are associated with the tumor cells themselves. While activity can be detected in normal colon tissue, this is localized to focal regions within the colonic epithelium, and only basally in the epithelial cells. Tumor tissue has a much broader, intense, and diffuse pattern of protease expression (Fig. 2).

Cysteine protease activity is primarily attributable to cathepsin B. Approximately $95 \%$ of the activity against the general cysteine protease substrate Z-Phe-Arg-AMC can be inhibited with the cathepsin B-specific inhibitor CA074 (18). This inhibitor binds to the occluding loop of cathepsin B, which is not present in other members of the papain superfamily, like cathepsin L, S or K. Immunolocalization of cathepsin B shows an extracellular distribution within bands of stroma, particularly at the leading edge of tumor invasion (Fig. 2). The intensity of cathepsin B expression at the interface of invading tumor and stroma supports previous hypotheses of a role for this enzyme in degradation of extracellular matrix during tumor growth (19-21). In situ hybridization shows that macrophages present at the interface of tumor and stroma are the major source of cathepsin B (Fig. 3).

The major serine protease activity is attributable to mast cell tryptase and chymase. Mast cells are abundant in the normal colon adjacent to tumor tissue (Fig. 2). Whether mast cellderived proteases are serving in a host-protec- tive function or are actually involved in tumor progression is an area of active investigation. Although not abundant within the tumor itself, mast cells in adjacent colon may contribute to neoplastic progression by both direct and indirect mechanisms. They directly affect neovascularization by liberation (upon degranulation) of diverse agents known to enhance angiogenic phenotypes, including heparin, heparinase, histamine, metallo- and serine proteinases, and various polypeptide growth factors, including basic fibroblast growth factor and vascular endothelial cell growthlvascular permeability factor (22-26). Indirectly, mast cells have been suggested to potentiate angiogenesis and neoplastic tissue remodeling via the actions of mast cell-chymase and -tryptase (Coussens et al., manuscript submitted). Tryptase activates prostromelysin- 1 and procollagenase-1 (27), in addition to possessing mitogenic activity for stromal fibroblasts and morphogenic activity towards capillary endothelial cells $(28,29)$. In contrast, chymase possesses neither mitogenic nor morphogenic activity; however, chymase initiates activation of pro-angiogenic progelatinase B/MMP-9 and liberates sequestered angiogenic activity from premalignant nonangiogenic tissue $(30,31$, Coussens et al., manuscript submitted). While mast cell-derived proteases are the most abundant activity in the adjacent normal colon biopsies, there is also uPA, a novel and unidentified trypsin-like protease, and cathepsin D activity. These latter proteases also could contribute to tumor progression indirectly (e.g., in angiogenesis, growth factor or protease activation), as argued for the mast cell proteases, and should not be ignored as potential targets for inhibitor development. There is significant variation in protease activity among tissue samples from different patients. Since this is a retrospective study, we cannot rule out some variation with sampling and storage conditions. However, we favor the explanation that this observation reflects variation among individual tumors in protease expression. This would not be unexpected, as the genetic instability characteristic of tumor progression may lead to abnormal expression or regulation of one or another protease cascade normally activated in wound repair or developmental programs. Such variation in protease activity would have significance for inhibitor development and clinical application, in that inhibition of specific proteases may be more appropriate in some patients than in others, 
and combinations of inhibitors may be warranted in certain situations. We specifically used assays that were sensitive enough to detect proteases in small tissue samples, including needle aspirates; could be readily automated; and, in most cases, did not require unusual or costly substrates. These assays are adaptable to robotics-driven automation. This should encourage future studies to develop and apply an automated "protease profile" assay suitable for evaluating individual surgical or cytological biopsy specimens prospectively.

\section{Acknowledgments}

The authors thank William Stetler-Stevenson, Bonnie Sloane, and Ellen Kick for reagents; the UCSF Liver Center Clinical Core for normal human liver samples; Mark Segal, Division of Biostatistics, UCSF, for consultation on statistical analysis; and Ramona Soto for preparation of the manuscript. This work was supported by a National Cancer Institute Program Project Grant \#CA72006-02.

\section{References}

1. Imai K, Yokohama Y, Nakanishi I, et al. (1995) Matrix metalloproteinase 7 (matrilysin) from human rectal carcinoma cells. Activation of the precursor, interaction with other matrix metalloproteinases and enzymic properties. J. Biol. Chem. 270: 6691-6697.

2. Thewes M, Pohlmann G, Atkinson M, Mueller J, Putz B, Hofler H. (1996) Stromelysin-3 (ST-3) mRNA expression in colorectal carcinomas. Localization and clinicopathologic correlations. $\mathrm{Di}$ agnostic Mol. Path. 5: 284-290.

3. Campo E, Munoz J, Miquel R, et al. (1994) Cathepsin B expression in colorectal carcinomas correlates with tumor progression and shortened patient survival [see comments]. Am. J. Path. 145: 301-309.

4. Gallegos N, Smales C, Savage F, Hembry R, Boulos P. (1995) The distribution of matrix metalloproteinases and tissue inhibitor of metalloproteinases in colorectal cancer. Surg. Oncol. 4: 111-119.

5. McDonnell S, Navre M, Coffey R, Matrisian L. (1995) Expression and localization of the matrix metalloproteinase pump-1 (MMP-7) in human gastric and colon carcinomas. Mol. Carcinogen. 4: 527-533.

6. Murray G, Duncan M, O'Neil, Melvin W, Fothergill. (1996) Matrix metalloproteinase- 1 is associated with poor prognosis in colorectal cancer. Nature Med. 2: 461-462.

7. Tran-Thang C, Kruithof E, Lahm H, Schuster WA, Tada M, Sordat B. (1996) Modulation of the plasminogen activation system by inflammatory cytokines in human colon carcinoma cells. Brit. J. Cancer 74: 846-852.

8. Buo L, Bjornland K, Karlsrud TS, et al. (1994) Expression and release of plasminogen activators, their inhibitors and receptor by human tumor cell lines. Anticancer Res. 14: 2445-245 1.

9. Stearns ME, Stearns M. (1996) Immunohistochemical studies of activated matrix metalloproteinase-2 (MMP-2a) expression in human prostate cancer. Oncol. Res. 8: 63-67.

10. Sinha AA, Wilson MJ, Gleason DF, Reddy PK, Sameni M, Sloane BF. (1995) Immunohistochemical localization of cathepsin B in neoplastic human prostate. Prostate 26: 171-178.

11. Sinha AA, Gleason DF, Staley NA, Wilson MJ, Sameni M, Sloane BF. (1995) Cathepsin B in angiogenesis of human prostate: an immunohistochemical and immunoelectron microscopic analysis. Anat. Rec. 241: 353-362.

12. Hoyhtya M, Fridman R, Komarek D, et al. (1994) Immunohistochemical localization of matrix metalloproteinase 2 and its specific inhibitor TIMP-2 in neoplastic tissues with monoclonal antibodies. Intl. J. Cancer 56: 500505.

13. Thewes M, Pohlmann G, Atkinson M, Mueller J, Putz B, Hofler H. (1996) Stromelysin-3 (ST-3) mRNA expression in colorectal carcinomas. Localization and clinicopathologic correlations. Diag. Mol. Path. 5: 284-290.

14. Johnson LD, Hunt DM, Kim K, Nachtigal M. (1996) Amplification of stromelysin-3 transcripts from carcinomas of the colon. Human Path. 27: 964-968.

15. Miyajima Y, Nakano R, Morimatsu M. (1995) Analysis of expression of matrix metalloproteinases-2 and -9 inhypopharyngeal squamous cell carcinoma by in situ hybridization. Ann. Otol. Rhinol. Laryngol. 104: 678-684.

16. Polette M, Clavel C, Birembaut P, De Clerck YA. (1993) Localization by in situ hybridization of mRNAs encoding stromelysin 3 and tissue inhibitors of metallo-proteinases TIMP-1 and TIMP-2 in human head and neck carcinomas. Path. Res. Prac. 189: 1052-1057.

17. Zeng Z, Guillem J. (1995) Distinct pattern of matrix metalloprotreinase-9 and tissue inhibitor of metalloproteinase-1 mRNA in human colorectal cancer and liver metastases. Brit. J. Cancer 72: 575-582.

18. Murata M, Miyashita S, Yokoo C, et al. (1991) Novel epoxysuccinyl peptides. Fed. Eur. Biochem. Soc. 280: 307-310.

19. Emmert-Buck MR, Roth MJ, Zhuang Z, et al. (1994) Increased gelatinase A (MMP-2) and 
cathepsin B activity in invasive tumor regions of human colon cancer samples. Am. J. Path. 145: 1285-1290.

20. Reddy VY, Zhang Q-Y, Weiss SJ. (1995) Pericellular mobilization of the tissue-destructive cysteine proteases cathepsins B, L and S by human monocyte-derived macrophages. Proc. Natl. Acad. Sci. 92: 3849-3853.

21. Berquin IM, Sloane BF. (1996) Cathepsin B expression in human tumors. Adv. Exp. Med. Biol. 389: 281-294.

22. Meininger C. (1995) Mast cells and tumorassociated angiogenesis. In Marone G (ed.) Human Basophils and Mast Cells: Clinical Aspects. Kerger, Basel Switzerland, pp. 238-256.

23. Bashkin P, Razin E, Eldor A, Vlodavsky I. (1990) Degranulating mast cells secrete an endoglycosidase which degrades heparin sulfate in subendothelial extracellular matrix. Blood 75: 2204-32212.

24. Vlodavsky I, Eldor A, Haimovitz-Friedman A, et al. (1992) Expression of heparanase by platelets and circulating cells of the immune system: Possible involvement in diapedesis and extravasation. Inv. Metast. 12: 112-127.

25. Reed JA, Albino AP, McNutt NS. (1995) Human cutaneous mast cells express basic fibroblast growth factor. Lab. Invest. 72: 215-222.

26. Grutzkau GA, Kruger-Krasagakes S, Baumeister $\mathrm{H}$, et al. (1998) Synthesis, storage, and release of vascular endothelial growth factor/vascular permeability factor (VEGF/VPF) by human mast cells: implications for the biological significance of VEGF206. Mol. Biol. Cell. 9: 875-884.

27. Norrby K, Wooley DE. (1993) Role of mast cells in mitogenesis and angiogenesis in normal tissue and tumor tissue. Adv. Biosci. 89: 71-115.

28. Blair RJ, Meng H, Marchese MJ, et al. (1997) Human mast cells stimulate vascular tube formation. J. Clin. Invest. 99: 2691-2700.

29. Gruber BL, Kew RR, Jelaska A, et al. (1997) Human mast cells activate fibroblasts. J. Immunol. 158: $2310-2317$.

30. Fang K, Raymond WW, Blount J, Caughey GH. (1997): Dog mast cell a-chymase activates progelatinase B by cleaving the Phe88-Gln89 and Phe9l-Glu92 bonds of the catalytic domain. J. Biol. Chem. 272: 25628-25635.

31. Vu TV, Shipley JM, Bergers G, et al. (1998) Matrix metalloproteinase gelatinase $\mathrm{B}$ is a key regulator of growth plate angiogenesis and apoptosis of hypertrophic chondrocytes. Cell 93: 411-422. 